"Supporting Information"

\title{
Replacement of the N-terminal Tyrosine Residue in Opioid Peptides with 3-(2,6- Dimethyl-4-carbamoylphenyl)propanoic Acid (Dcp) Results in Novel Opioid Antagonists
}

Yixin Lu, ${ }^{\dagger}{ }^{\dagger}$ Tze Keong Lum, ${ }^{\dagger}$ Yoon Wui Leow Augustine, ${ }^{\dagger}$ Grazyna Weltrowska ${ }^{\ddagger}$, Thi M.-D. Nguyen, ${ }^{\ddagger}$ Carole Lemieux,${ }^{\ddagger}$ Nga N. Chung, ${ }^{\ddagger}$ and Peter W. Schiller* ${ }^{*}$

${ }^{\dagger}$ Department of Chemistry, National University of Singapore, 3 Science Drive 3, Singapore 117543, Singapore, and ${ }^{\ddagger}$ Laboratory of Chemical Biology and Peptide Research, Clinical Research Institute of Montreal, 110 Pine Avenue West, Montreal, Quebec, Canada H2W $1 R 7$

\section{Experimental Section}

General Methods. Molecular masses of the compounds were determined by electrospray mass spectrometry on a Hybrid Q-Tof mass spectrometer interfaced to a MassLynx 4.0 data system or on a Finnigan/MAT 95XL-T spectrometer. ${ }^{1} \mathrm{H}$ and ${ }^{13} \mathrm{C}$ NMR spectra were recorded on a Varian Unity 400 spectrometer or a Bruker Model Avance $300 \mathrm{MHz}$ or DPX-300 NMR spectrometer, and referenced with respect to the residual signals of the solvent. The following abbreviations were used in reporting spectra: $\mathrm{s}=$ singlet, $\mathrm{d}=$ doublet, $\mathrm{t}=$ triplet, $\mathrm{q}=$ quartet, $\mathrm{m}=$ multiplet, $\mathrm{dd}=$ doublet of doublets. Compounds $\mathbf{5}, \mathbf{8}$, 9 and 10 were purified by flash chromatography on silica gel ( $40 \mu \mathrm{m}$; Baker). Peptides were purified on a Vydac 218-TP1022 column $(22 \times 250 \mathrm{~mm})$ with a linear gradient of $20-80 \% \mathrm{MeOH}$ in $0.1 \%$ TFA over $30 \mathrm{~min}$ at a flow rate of $12 \mathrm{~mL} / \mathrm{min}$ (peptides 1 and 2) or with a linear gradient of $20-65 \% \mathrm{MeOH}$ in $0.1 \%$ TFA over 50 in at a flow rate of 12 $\mathrm{mL} / \mathrm{min}$ (peptide 3). Analytical reversed-phase HPLC was performed on a Vydac 218TP54 column $(5 \times 250 \mathrm{~mm})$ under isocratic conditions $(35 \% \mathrm{MeOH}$ in $0.1 \% \mathrm{TFA})$ at a flow rate of $1 \mathrm{~mL} / \mathrm{min}$. The same column was also used for the determination of the capacity factors K' under the same conditions. Precoated plates (silica gel $60 \mathrm{~F}_{254}, 250$ $\mu \mathrm{m}$; Merck, Darmstadt, Germany) were used for ascending TLC in the following solvent systems (all v/v): (I) $n-\mathrm{BuOH} / \mathrm{AcOH} / \mathrm{H}_{2} \mathrm{O}$ (4:1:1), (II) $n-\mathrm{BuOH} /$ pyridine $/ \mathrm{AcOH} / \mathrm{H}_{2} \mathrm{O}$ $(15: 10: 3: 12)$.

In Vitro Bioassays and Receptor Binding Assays. The GPI ${ }^{16}$ and $\mathrm{MVD}^{17}$ bioassays were carried out as reported in detail elsewhere. ${ }^{18,19} \mathrm{~K}_{\mathrm{e}}$ values for antagonists were determined from the ratio of $\mathrm{IC}_{50}$ values obtained with an agonist in the presence and absence of a fixed antagonist concentration. ${ }^{20} \mu$ antagonist $\mathrm{K}_{\mathrm{e}}$ values of compounds were determined in the GPI assay against the $\mu$ agonist TAPP $^{21}$ using antagonist concentrations ranging from 10 to $500 \mathrm{nM}$. $\kappa$ antagonist $\mathrm{K}_{\mathrm{e}}$ values of compounds were 
also measured in the GPI assay against the $\kappa$ agonist U50,488, using antagonist concentrations ranging from 50 to $200 \mathrm{nM}$. $\delta$ antagonist $\mathrm{K}_{\mathrm{e}}$ values of compounds were determined in the MVD assay against the $\delta$ agonist DPDPE using antagonist concentrations ranging from 200 to $600 \mathrm{nM}$.

Opioid receptor binding studies were performed as described in detail elsewhere. ${ }^{18}$ Binding affinities for $\mu$ and $\delta$ receptors were determined by displacing, respectively, $\left[{ }^{3} \mathrm{H}\right]$ DAMGO (Multiple Peptide Systems, San Diego, CA) and $\left[{ }^{3} \mathrm{H}\right]$ DSLET (Multiple Peptide Systems) from rat brain membrane binding sites, and $\kappa$ opioid receptor affinities were measured by displacement of $\left[{ }^{3} \mathrm{H}\right] \mathrm{U} 69,593$ (Amersham) from guinea pig brain membrane binding sites. Incubations were performed for $2 \mathrm{~h}$ at $0{ }^{\circ} \mathrm{C}$ with $\left[{ }^{3} \mathrm{H}\right] \mathrm{DAMGO}$, $\left[{ }^{3} \mathrm{H}\right] \mathrm{DSLET}$, and $\left[{ }^{3} \mathrm{H}\right] \mathrm{U} 69,593$ at respective concentrations of $0.72,0.78$, and $0.80 \mathrm{nM}$. $\mathrm{IC}_{50}$ values were determined from log-dose displacement curves, and $\mathrm{K}_{\mathrm{i}}$ values were calculated from the obtained $\mathrm{IC}_{50}$ values by means of the equation of Cheng and Prusoff, $^{22}$ using values of $1.3,2.6$, and $2.9 \mathrm{nM}$ for the dissociation constants of $\left[{ }^{3} \mathrm{H}\right] \mathrm{DAMGO},\left[{ }^{3} \mathrm{H}\right] \mathrm{DSLET}$, and $\left[{ }^{3} \mathrm{H}\right] \mathrm{U} 69,593$, respectively.

\section{References}

(16) Paton, W.D.M. The Action of Morphine and Related Substances on Contraction and on Acetylcholine Output of Coaxially Stimulated Guinea Pig Ileum. Br. J. Pharmacol. 1957, 12, 119-127.

(17) Henderson, G.; Hughes, J.; Kosterlitz, H.W. A New Example of a Morphine Sensitive Neuroeffector Junction. Br. J. Pharmacol. 1972, 46, 764-766.

(18) Schiller, P.W.; Lipton, A.; Horrobin, D.F.; Bodanszky, M. Unsulfated C-terminal 7-Peptide of Cholecystokinin: a New Ligand of the Opiate Receptor. Biochem. Biophys. Res. Commun. 1978, 85, 1332-1338.

(19) DiMaio, J.; Nguyen, T.M.-D.; Lemieux, C.; Schiller, P.W. Synthesis and Pharmacological Characterization In Vitro of Cyclic Enkephalin Analogues: Effects of Conformational Constraints on Opiate Receptor Selectivity. J. Med. Chem. 1982, 25, 1432-1438.

(20) Kosterlitz, H.W.; Watt, A.J. Kinetic Parameters of Narcotic Agonists and Antagonists with Particular Reference to N-Allylnoroxymorphone (Naloxone). Br. J. Pharmacol. 1968, 33, 266-276.

(21) Schiller, P.W.; Nguyen, T.M.-D.; Chung, N.N.; Lemieux, C. Dermorphin Analogues Carrying an Increased Positive Net Charge in Their "Message Domain" Display Extremely High $\mu$ Opioid Receptor Selectivity. J. Med. Chem. 1989, 32, 698-703.

(22) Cheng, Y.C.; Prusoff, W.H. Relationship Between the Inhibition Constant $\left(\mathrm{K}_{\mathrm{I}}\right)$ and the Concentration of Inhibitor which Causes 50 Percent Inhibition $\left(\mathrm{I}_{50}\right)$ of an Enzymatic Reaction. Biochem. Pharmacol. 1973, 22, 3099-3102. 